\title{
STEPWISE HYDROLYSIS OF AMORPHIN
}

\author{
A. U. Kasymov, E. S. Kondratenko, and N. K. Abubakirov
}

Khimiya Prirodnykh Soedinenii, Vol. 6, No. 4, pp. 469-470, 1970

UDC $547.597+547.918$

It has been shown previously that amorphin, $\mathrm{C}_{34} \mathrm{H}_{40} \mathrm{O}_{16}$, a rotenoid diglycoside from plants of the genus Amorpha, is a vicianoside of amorphigenin [1,2]. However, the configuration of the glycosidic bond between the sugars was not strictly proved.

This can be done only by stepwise hydrolysis, although on acid hydrolysis both glycoside bonds of amorphin are cleaved simultaneously, with the formation of amorphigenin, D-glucose, and L-arabinose. For this reason, the intermediate hydrolysis product has not yet been detected [2]. Yashchenko's paper [3] on the isolation of an intermediate product does not agree with the already established structure of the sugar chain of amorphin.

In the course of a study of the stepwise hydrolysis of amorphin according to the concentration of the acids, the temperature, and the duration of heating, we selected conditions leading to the formation of the intermediate compound.

A solution of amorphin in $2 \% \mathrm{H}_{2} \mathrm{SO}_{4}$ was heated to the boil for $40 \mathrm{~min}$ and then cooled. The precipitate was shown by TLC on silica gel [benzene-methanol $(9: 1)$ ] to contain three substances in approximately equal amounts. The most polar of them proved to be unchanged amorphin, and the least polar was the aglycone of amorphin, amorphigenin $\mathrm{C}_{23} \mathrm{H}_{22} \mathrm{O}_{7}$.

To obtain the substance with the intermediate polar ity, the water-washed and dried precipitate was freed from amorphigenin by extraction with ether and then chromatographed on a column of silica gel in a benzene-methanol (6:1) system. A substance with the composition $\mathrm{C}_{29} \mathrm{H}_{34} \mathrm{O}_{12}, \mathrm{mp} 165-166^{\circ} \mathrm{C},[\alpha]_{\mathrm{D}}^{20}-122^{\circ}$ (c 0.1 , ethanol) was isolated which was identical in its chemical properties and UV and IR spectra with amorphigenin $\beta-\mathrm{D}$-glucopyranoside, which we found previously in some species of Amorpha [4]. The hydrolysis of this substance with $20 \% \mathrm{H}_{2} \mathrm{SO}_{4}$ led to amorphigenin and D-glucose.

Similar results were obtained when a solution of amorphin was heated with Amberlite IR-120 $\left(\mathrm{H}^{+}\right.$form) at $60-80^{\circ} \mathrm{C}$ for $2 \mathrm{hr}$. If we remember that the specific rotation of amorphin $[\alpha]_{\mathrm{D}}^{20}$ is $-98^{\circ}$ (ethanol), the difference in the molecular rotations of amorphin $[\mathrm{MI}]_{\mathrm{D}}-690^{\circ}$ and amorphigenin $\beta-\mathrm{D}-\mathrm{glucopyranoside}[\mathrm{M}]_{\mathrm{D}}-700^{\circ}$, is $+10^{\circ} \mathrm{C}$.

For methyl $\alpha$-arabopyranoside $[\mathrm{M}]_{\mathrm{D}}$ is $+28^{\circ}$ (water) and for methyl $\beta$-arabopyranoside $[\mathrm{M}]_{\mathrm{D}}$ is $403^{\circ}[5]$. These facts show that the glycoside bond of the arabinose in amorphin has the $\alpha$-configuration.

\section{RE FER EN C E S}

1. E. S. Kondratenko and N. K. Abubakirov, Uzb. khim. zh., no. 5, 66, 1961.

2. J. Claisse, L. Crombie, and R. Peace, J. Chem. Soc., suppl., 2, 6023, 1964.

3. V. K. Yashchenko, collection: Some Problems of Pharmacy [in Russian], Kiev, 251, 1956. $326,1968$.

4. A. U. Kasymov, E. S. Kondratenko, and N. K. Abubakirov, KhPS [Chemistry of Natural Compounds], 4,

5. Tollens-Elsner, Kurzes Handbuch der Kohlenhydrate [Russian translation], Moscow-Leningrad, $139,1938$.

16 March 1970

Institute of the Chemistry of Plant Substances, AS UzSSR 